\title{
Anionic Surfactunt Determination at the Anzali Wetland, Iran
}

\author{
Azemat Ghandi", Hojat Khodaparast, Hadi Babaei, Afshin Fahim \\ Inland Waters Aquaculture Research Center, Iranian Fisheries Sciences Research Institute, Agricultural Research Education and Extension \\ Organization (AREEO), Anzali, Iran
}

Email address:

azematghandi@yahoo.com(A. Ghandi)

${ }^{*}$ Corresponding author

To cite this article:

Azemat Ghandi, Hojat Khodaparast, Hadi Babaei, Afshin Fahim. Anionic Surfactunt Determination at the Anzali Wetland, Iran. Journal of Chemical, Environmental and Biological Engineering. Vol. 2, No. 1, 2018, pp. 1-4. doi: 10.11648/j.jcebe.20180201.11

Received: October 21, 2017; Accepted: March 11, 2018; Published: May 30, 2018

\begin{abstract}
Surfactant is pollutants that enter in to water ecosystem through industrial and urban sewages. The objective of this project is to determine the level of LAS and seasonal trend in eight different station of the Anzali wetland and compare them with maximum allowable value. In the study 96 samples of water were extracted by liquid-liquid method and the LAS were determined as methylene blue active substances (MBAS).The concentration of surfactant in the Pirbazar and the Caspian Sea stations varied from 0.176 to 0.422 , and 0.098 to $0.049 \mathrm{mg} / 1$ while the seasonal concentration varied from 0.49 to 0.422 $\mathrm{mg} / \mathrm{l}$. The significant different were observed solely in the eastern of the Anzali wetland at the Pirbazar station $(\mathrm{P}<0.05)$. The results showed that the highest of surfactant level measured about $0.27 \pm 0.10 \mathrm{mg} / 1$ at the Pirbazar station and the lowest recorded with $0.066 \pm 0.022 \mathrm{mg} / \mathrm{l}$ in the Caspian Sea. The seasonal variations displayed, surfactant concentrations varied between $0.17 \pm 0.07$ and $0.10 \pm 0.06 \mathrm{mg} / 1$ in winter and spring respectively, and average of $0.137 \pm 0.037 \mathrm{mg} / \mathrm{l}$. By the way no significant different were detected between seasons. In spite of this, LAS amount in water with other chemical material can create unfavorite effect on this ecosystem.
\end{abstract}

Keywords: Anzali Wetland, Surfactant, Anionic

\section{Introduction}

The Anzali wetland is one of the biggest wetland in Iran and is one of the most valuable wetland worlds. The ecologic variety, seasonal changes, wild life cause to make this wetland as unique ecosystem that has special place in the list of valuable international wetlands of Ramsar convention (consultant engineer grade 1,1367). Domestic and industrial sewage enter directly or indirectly to these water ecosystems and pollute these ecosystems [1].

Among different pollutants, washing materials are more important for their use and also they are very dangerous for aquatic animals, though washing materials can be decomposed by special bacteria, but in high density, bacteria activity can be stopped or limited that its reason is pollutant $\mathrm{s}$ preventive action on bacteria enzymes that are necessary for decomposition of pollutant [2].

Biological decomposition of pollutants in places that pollution is very high is impossible. Watery systems in different grade are able to attract specific level of toxic materials, but when pollutant material become more than specific level, self-strainer method can be changed and its effect on aquatic animals be clear. Any types of Surfactants can be used in washing materials and they have industrial usage such as nutrition, medical industries, agricultural toxin, loom, wood, plastic, painting, leather production, photography, firefighting [3].

In watery ecosystems often surfactants density is less than $0.1 \mathrm{mg} / \mathrm{l}$ except river watercourse and places that have more pollution source [4].

Washing materials trend to be on the top surface of water, therefore decrease oxygen $\mathrm{s}$ exchange with shallow water that this occurrence is very common in sewage evacuation, and creates weight blubbers in the river [5].

Surfactants can be divided to four groups that are following as: Anion surfactants, Cation surfactant, Unionic surfactant, amphoteric surfactants [2].

This study purpose had been determining of LAS amount in determined stations of Anzali wetland and also its seasonal 
changes and comparison with permissive maximum density of washing materials in ecosystem.

\section{Materials and Methods}

\subsection{Study Area}

The area under investigation is located in the Anzali wetland. It is with a catchment area of $3740 \mathrm{~km} 2$ contribute about 2 million $\mathrm{m} 3$ freshwater per year [6] and water is supplied by 19 inlet rivers and connected to the Caspian Sea through 2 outlet river. The wetland represents an internationally important wildlife reserve and sanctuary which is listed under Ramsar Convention [7]. During the last decades, the wetland has been threatened and destroyed by environmental pollution from seven identified sources of rivers, municipal, industrials, commercials, mines, agricultural, and hospitals [8,9].

\subsection{Sample Collection}

Sampling in 8 Anzali wetland stations has been performed as
3 repetitions (Pir bazar, Pasikhan, centeral wetland, Siakishim, West wetland, Shanbehbazar, Moojshekan and Sea; Figure 1).

For experiment, first Methyllen blue, chloroform and proponnol solution has been supplied. Extraction and measurement of surfectants has been performed by methyllen blue method and, spectrophotometry has been performed by year method [4]. Methyllen blue and surfectant has created complex that is more stable in $\mathrm{pH} 8$ or 8.2 and extraction has been performed by decanter cone with mixture of Methyllen blue, chloroform and proponnol solution 1: 5: 5 and 12.5 and has been mixed severely in 30 seconds until liquid and organic phase will be separated and extraction will be repeated with adding $5 \mathrm{ml}$ chloroform and choloroform add to other cone and $25 \mathrm{ml}$ washing solution added to other cone and mixed severally in 30 seconds, and after mix of two other phase, separation has been performed in any stage by $5 \mathrm{ml}$ chloroform. Organic phase has been transfered to JoJeh ballon and final solution volume become $50 \mathrm{ml}$, then by spectrophotometer device in wavelength 652, sample attraction was declared.

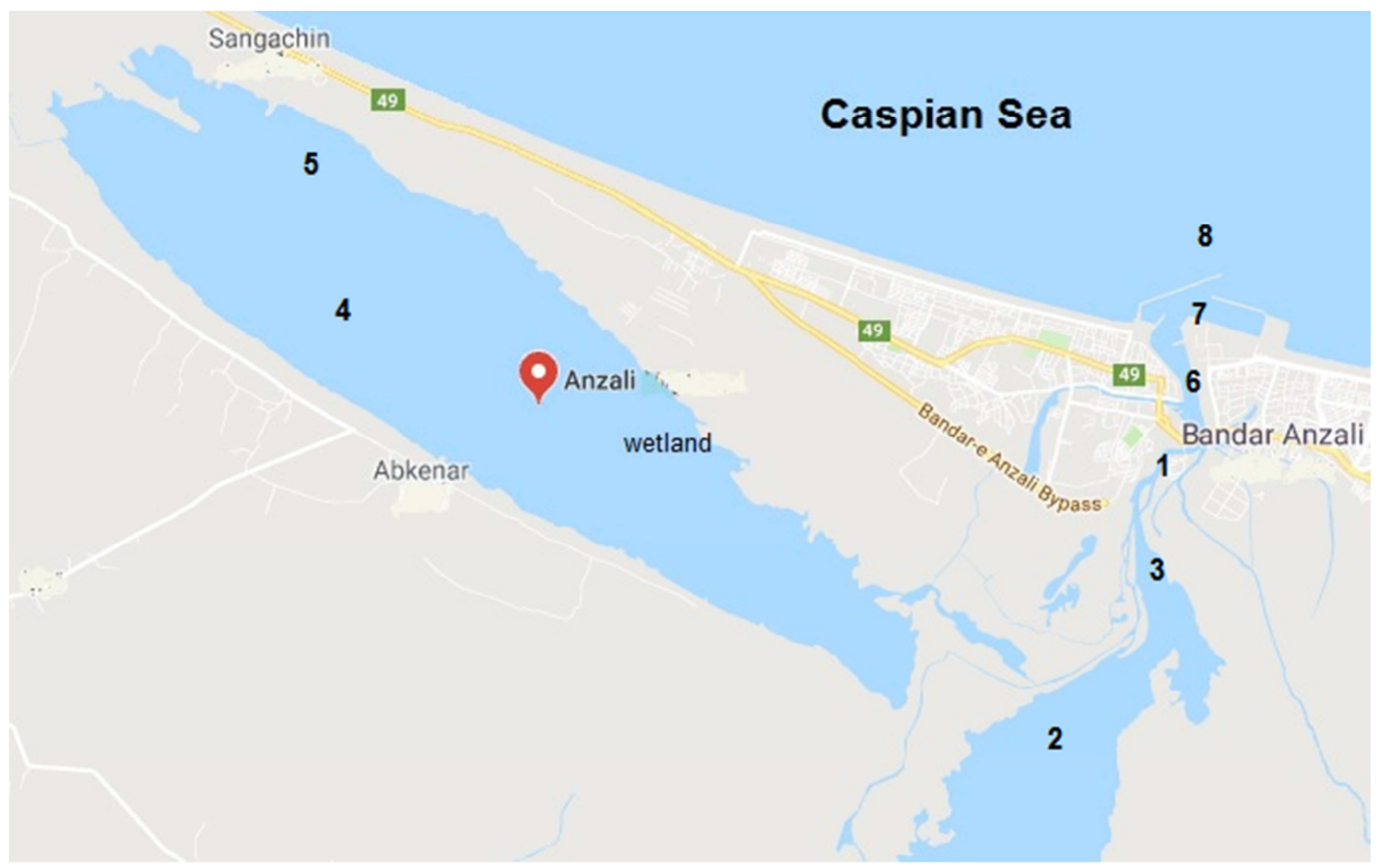

Figure 1. Map of the study area and sampling stations in the Anzali wetland, Iran (Taken from: Google map).

\section{Results}

Table 1 showed the LAS amount in different season. In this table yearly minimum and maximum of LAS washing material has been declared.

Table 1. Amount of LAS washing material (mg/l) in the Anzali wetland, 2002.

\begin{tabular}{|c|c|c|c|c|c|c|c|c|c|}
\hline \multirow{2}{*}{ no } & \multirow{2}{*}{ Station } & \multicolumn{8}{|l|}{ Season } \\
\hline & & Spring & Summer & Autumn & Winter & Average & SD & Minimim & Maximum \\
\hline 1 & Pirbazar & 0.261 & 0.422 & 0.176 & 0.278 & 0.273 & 0.108 & 0.176 & 0.422 \\
\hline 2 & Pasikhan & 0.134 & 0.072 & 0.141 & 0.232 & 0.145 & 0.066 & 0.072 & 0.232 \\
\hline 3 & Center & 0.078 & 0.118 & 0.131 & 0.167 & 0.124 & 0.037 & 0.078 & 0.167 \\
\hline 4 & Siakeshim & 0.069 & 0.118 & 0.134 & 0.118 & 0.11 & 0.028 & 0.069 & 0.134 \\
\hline
\end{tabular}




\begin{tabular}{|c|c|c|c|c|c|c|c|c|c|}
\hline \multirow{2}{*}{ no } & \multirow{2}{*}{ Station } & \multicolumn{8}{|l|}{ Season } \\
\hline & & Spring & Summer & Autumn & Winter & Average & SD & Minimim & Maximum \\
\hline 5 & West & 0.049 & 0.069 & 0.108 & 0.147 & 0.093 & 0.043 & 0.049 & 0.147 \\
\hline 6 & Shanbehbazar & 0.167 & 0.216 & 0.137 & 0.245 & 0.191 & 0.048 & 0.137 & 0.024 \\
\hline 7 & Moojshekan & 0.059 & 0.095 & 0.108 & 0.118 & 0.095 & 0.026 & 0.059 & 0.118 \\
\hline \multirow[t]{3}{*}{8} & Sea & 0.059 & 0.098 & 0.059 & 0.049 & 0.066 & 0.022 & 0.049 & 0.098 \\
\hline & Average & 0.104 & 0.151 & 0.124 & 0.169 & 0.137 & & & \\
\hline & $\mathrm{SD}$ & 0.061 & 0.119 & 0.034 & 0.077 & 0.073 & & & \\
\hline
\end{tabular}

Seasonal change mean of LAS density is offered in table 1, as observed in summer, change level is maximum and in autumn change level of LAS is minimum and winter has more changes level in comparison to spring, whereas maximum level is observed in summer. From LAS density minimum view point, spring and winter are same and spring has least mean, namely $0.104 \mathrm{mg} / \mathrm{l}$. The results showed that the highest of surfactant level measured about $0.27 \pm 0.10$ $\mathrm{mg} / \mathrm{l}$ at the Pirbazar region and the lowest recorded with $0.066 \pm 0.022 \mathrm{mg} / \mathrm{l}$ in the Caspian Sea (Figure 2).

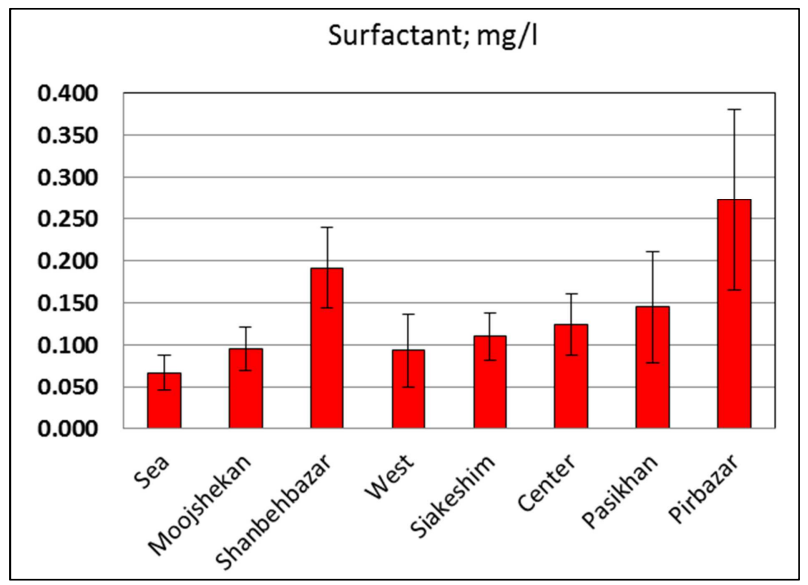

Figure 2. Surfactant concentration in different stations in the Anzali wetland, 2002.

The seasonal variations displayed, surfactant concentrations varied between $0.17 \pm 0.07$ and $0.10 \pm 0.06$ $\mathrm{mg} / \mathrm{l}$ in winter and spring respectively and average of $0.137 \pm$ $0.037 \mathrm{mg} / 1$ (Figure 3). By the way no significant different were detected between seasons $(\mathrm{P}>0.05)$.

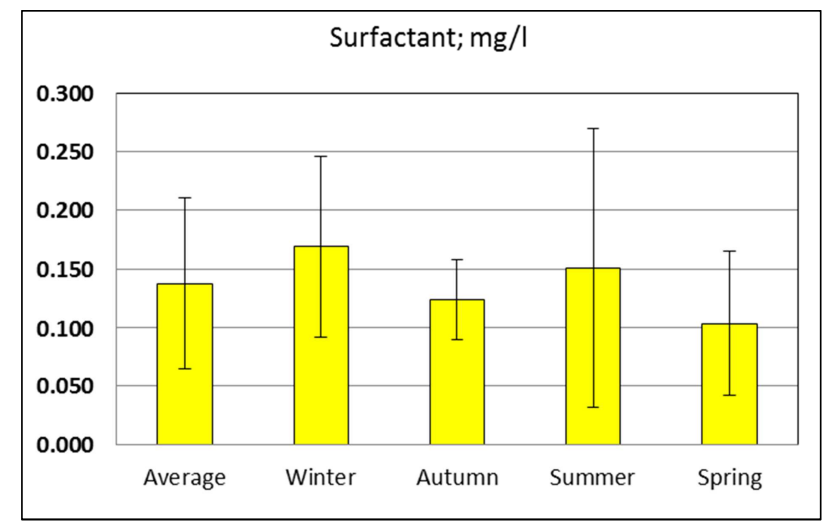

Figure 3. Surfactant concentration in different season in the Anzali wetland, 2002.

\section{Discussion}

Increase of population and increasing use of different washing material cause to high volume of LAS and additional material enter to wetland and influence aquatic animal and wetland trophy pattern so they have important role in creation of wetland eutrophication environment.

Results of these studies shows that seasonal mean of LAS density was $0.137 \mathrm{mg} / \mathrm{l}$. Maximum seasonal amount of LAS was in winter season with $0.169 \mathrm{mg} / \mathrm{l}$ and minimum amount was referred to spring season with $0.104 \mathrm{mg} / 1$.

Khorasani [3] reported maximum density of LAS in winter. With attention to this fact that both of measurements in two stage was performed in March, therefore has been concluded that washing of domestic furnishings by use of washing materials before Iranian new year show high effect in high density of LAS in this reason that indicate effect of human activity in the Anzali wetland system.

Regional comparison indicates that the Siahkeshim wetland and the west wetland after the Sea and the Moojshekan stations have least density of LAS. Watershed of these regions has few populations and effect of human activity from LAS use view point is very weak.

The sea and the Moojshekan stations with mean of 0.066 and $0.095 \mathrm{mg} / 1$ have been minimum LAS amount. In these stations by reason of high hardness of seawater (high calcium) washing materials accumulate and sediment that decreased LAS density in water. The Pirbazar station with mean of $0.273 \mathrm{mg} / 1$, minimum 0.176 and maximum 0.422 $\mathrm{mg} / \mathrm{l}$ has highest LAS concentrations. This station is influenced severely by human population activity in its watershed. Unresolved sewage of Rasht city and some villages, enter to the Anzali wetland by the Pirbazar river that is cause of high density of LAS in this region.

Most of LAS after encounter to hard water of Sea and wetland sediment and phosphor of LAS is effective in fertility of wetland, in other hand LAS as chemical component has negative effects on aquatics animals especially primary users. On the basis of previous studies, primary producers are more resistant against to LAS in comparison to other energy levels. Effect of washing materials on zooplanktons is more than algae, approximately, density of washing material that is cause of death in more than $50 \%$ of zooplankton is between $7.5-52 \mathrm{mg} / \mathrm{l}$ but about algae this density is between 83-314 mg/l [5] Therefore registered amount is very lower than level that can have negative effect on algae and zooplankton.

Different washing materials and detergents create different effect on aquatic animals. Investigation has showed that dish 
washer liquid has more effect on zooplanktons death and also soap powders are more dangerous than washing machine powder [5].

Little detergents can break proteins of cell plasma membrane and cause to oil hydro carbor enters to cell [10]. Also petroleum products change to small drop by LAS and enter to organism and create negative effect on animal and human population structure by decrease of nutrition, growth coefficient and reproduction [11,]

In east district, that many chemical pollutant such as oil hydro carbor, metal mineral, loom pollutant, agricultural toxins, domestic sewage and LAS enter to wetland ecosystem can increase LAS effects and create sever ecologic disorders in wetland [12].

Decrease of LAS density by coagulation and sedimentation is dangerous for aquatics animals that live in sea bed $[13,14]$. On the basis of WHO standard, suitable deal of LAS water ecosystems is $0.2 \mathrm{mg} / \mathrm{l}$ and maximum density is $1 \mathrm{mg} / \mathrm{l}$.

\section{Conclusion}

Measured density in all of stations is lower than permissive maximum that has been determined by (WEPA) world environmental protection agency. In spite of this, LAS amount in water with other chemical material can create unfavorite effect on this ecosystem. In other hand, in this study, sampling was seasonal and may be high deal of LAS is in this region in other times.

\section{References}

[1] Ghatak, D. B. and Konar, S. K., 1993. Chronic sublethale efects of heavy metal cadmium, pesticide DDvp, detergentparnoI-JandPetroIeumproductn-Heptaneon fish. Environmental Ecology. 11 (4):778-783.

[2] Hynes, H. B. N, 1966. The Biology of polluted waters. Liverpool University Press. England. TD420. H9 1974 155167.

[3] Khorasani, M. 1993. Determination of surfactant in the Anzali wetland. Fisheries Research Center of Guilan Province, Anzali. 79 pp.
[4] APHA, 2005. Standard method for the examination of water and wastewater. Washigton, DC, USA. 1265 P.

[5] Piri, M. Fallahi, M. 1998. The effect of detergent on deaths Daphnia magna. Iranian Journal of Scientific Fisheries. 6: 6982.

[6] Bagheri, S., Mansor, M., Makaremi, M., Sabkara, J., WanMaznah, W. O., Mirzajani, A., Khodaparast, SH., Negarestan, H., Ghandi, A. and Khalilpour, A. 2011. Fluctuations of phytoplankton community in the coastal waters of Caspian Sea in 2006. American Journal of Applied Sciences, 8: 13281336 .

[7] Pourang, N. 1996. Heavy metal concentrations in surficial sediments and benthic macroinvertebrates from Anzali wetland, Iran, Hydrobiologia. 331 (1): 53-6.

[8] Bagheri, S., Niermann, U., Sabkara, J. and Babaei, H. 2012. State of Mnemiopsis leidyi (Ctenophora:Lobata) and mesozooplankton in Iranian waters of the Caspian Sea during 2008 in comparison with previous surveys. Iran Journal of Fisheries Sciences. 11 (4): 732-754.

[9] Bagheri, S., Niermann, U., Mansor, M and Yeok, F. S. 2014. Biodiversity, distribution and abundance of zooplankton in the Iranian waters of the Caspian Sea off Anzali during 19962010. Journal of the Marine Biological Association of the United Kingdom. 94:129-140.

[10] Nelson, S. A. 1973. Oil pollution and marine ecology. Plenum press, New York, USA. pp, 92-94.

[11] Renzi, M., Giovani, A. and Focardi, S. 2012. Water pollution by surfactants fluctuations due to tourism exploitation in a lagoon ecosystem. Journal of environmental protection. 9 (3): 1004-1009.

[12] Jimenes-Castareda, M, E. and Medina, D. I. 2017. Use of surfactant-modified zeolies and clays for the removal of Heavy metals. Water. 9 (4): 235-249.

[13] Yuan, C. L., Xu, Z. Z., Fan, H. Y., Liu, Y. H and Zhu, T. 2014. Study on characteristics and harm of surfactants. Journal of chemical and pharmaceutical research. 6 (7): 2233-2237.

[14] Chattopadhyay, D. N. and Konar, S. K. 1985. Acute and chronic of alkyl benzene on aquatic ecosystems. Environmental ecology. 3: 268-262. 